\title{
Marcin Potrykus*
}

\section{INWESTYCJA W WINO - OCENA SOMMELIERÓW, ROCZNIK I LICZBA PUNKTÓW DYSTRYBUCJI A WYCENA}

\section{Wprowadzenie}

W ramach rynku inwestycji alternatywnych (AIM - Alternative Investments Market) inwestor ma do wyboru szeroki wachlarz dostępnych produktów. Wyróżnić można pięć głównych kategorii inwestycyjnych tego rynku: inwestycje w fundusze hedgingowe, inwestycje w surowce, inwestycje na rynku nieruchomości, inwestycje na rynku walutowym i inwestycje emocjonalne. Do tych ostatnich należy inwestycja w wino, która obok inwestycji w koniak i whisky reprezentuje rodzaj inwestycji w alkohole. Wino często nazywa się płynnym złotem (liquid gold), ze względu na podobieństwa pomiędzy inwestycją w złoto a pomnażaniem kapitału na drodze zakupu wina. Do największych producentów win na świecie zalicza się: Francję, Włochy, Hiszpanię, Austrię, Niemcy i Portugalię. Coraz większe znaczenie na rynku winiarskim odgrywają także takie kraje jak: Stany Zjednoczone, Australia czy Chile. Praca przy produkcji win stanowi dla niektórych regionów na świecie (np. Rioja w północnej Hiszpanii) główne źródło zatrudnienia i bogactwa ${ }^{1}$. Pomnażanie kapitału poprzez handel na rynku win charakteryzuje się w ostatnich latach rosnącym dynamicznie zainteresowaniem ze strony inwestorów ${ }^{2}$. Można wręcz spotkać opracowania wskazujące na występowanie cenowej „bańki spekulacyjnej” na rynku ekskluzywnych win francuskich z rejonu Bordeaux ${ }^{3}$, które są przedmiotem niniejszego opracowania. Niewątpliwie do rozwoju analizowanego rynku przyczyniło się powstanie w 1999 r. londyńskiej giełdy Liv-ex ${ }^{4}$.

* Politechnika Gdańska, Wydział Zarządzania i Ekonomii.

1 F. Gómez-Bezares, M. Larreina, An Approach to the Valuation of Rioja Wine, "Journal of Wine Research" 2008, Vol. 19(1), s. 33-50.

2 R. Campbell, Fine violins as an alternative investment: Strings attached?, "Pensions: An International Journal" 2008, Vol. 13 (1-2), s. 89-96; C. Veld, Y.V. Veld-Merkoulova, Benefits of Investing in Stamps, "The Journal of Alternative Investments" 2007, s. 56-62.

3 B. Jovanovic, Bubbles in prices of exhaustible resources, "International Economic Review" 2013, Vol. 54(1), s. 1-35.

4 http://liv-ex.com/, dostęp 25.04.2014. Powstanie giełdy zwiększyło płynność rynku. Ograniczona płynność inwestycji alternatywnych to, po wysokich opłatach, drugi najczęściej wymieniany czynnik 


\section{Inwestycja w wino - przegląd literatury}

W Polsce inwestycje w wino nie są popularną formą pomnażania kapitału. Do najbardziej aktywnych narodowości na wskazanym rynku zalicza się Brytyjczyków, Amerykanów, Portugalczyków, Rosjan i mieszkańców Dalekiego Wschodus. To właśnie zwiększona aktywność inwestorów z Dalekiego Wschodu przyczynia się do wysokich cen dla niektórych szczepów i roczników oraz do stwierdzenia, że także na tym rynku mogą występować „bańki spekulacyjne”. W wino można inwestować bezpośrednio ${ }^{7}$ poprzez zakup skrzynek $\mathrm{z}$ wybranym trunkiem ${ }^{8}$ lub poprzez inwestycję $\mathrm{w}$ wino leżakujące (en primeur) ${ }^{9}$. Inna możliwość inwestowania $\mathrm{w}$ alkohole to forma pośrednia, do której należy zakup jednostek uczestnictwa funduszy inwestycyjnych, związanych z rynkiem winnym ${ }^{10}$.

W opracowaniach dotyczących tematyki inwestycji w wina można odnaleźć próby budowy indeksu cen dla tego rynku ${ }^{11}$ lub określenie stopy zwrotu z portfela inwestycyjnego składającego się z inwestycji w wino i innych inwestycji. Podkreśla się bowiem, że inwestycja w wino pozwala na dywersyfikację portfela inwestycyjnego. Jest to możliwe dzięki zerowej korelacji pomiędzy stopą zwrotu $\mathrm{z}$ inwestycji $\mathrm{w}$ wino oraz stopami zwrotu $\mathrm{z}$ inwestycji tradycyjnych ${ }^{12}$. Jednak zakup wina nie stanowi jedynie uzupełnienia dobrze zdywersyfikowanego portfela inwestycyjnego, dzięki wysokiej stopie zwrotu inwestycja w wino może być także rozważana jako najważniejszy jego element ${ }^{13}$.

Wyniki do tej pory przeprowadzonych badań nad stopą zwrotu z inwestycji $\mathrm{w}$ wino przedstawiono $\mathrm{w}$ tabeli 1.

zniechęcający do zawierania transakcji na AIM (Raport Morningstar and Barron's 2013).

5 B. Drewnowska, Inwestycje w wino moga być alternatywa dla akcji, „Rzeczpospolita” 17.04.2008.

6 W. Chmielarz, Wino, czyli alternatywa, „Puls Biznesu” 3.07.2008, s. 14.

7 Do bezpośrednich form inwestowania na rynku win można także zaliczyć zakup winnicy lub jej części.

8 Na skrzynkę wina najczęściej składa się 12 butelek o pojemności 0,751 .

9 Inwestycja w wino leżakujące polega na zakupie beczek $\mathrm{z}$ winem, których zawartość w przyszłości zostanie rozlana do butelek.

${ }^{10}$ Fundusze inwestujące w wino to np.: Wine Growth Found, Vintage Wine Found, Vinum Fine Wine Found, Orange Wine Found, The Bottled Assets Found, Wine Asset Managers, The Wine Investment Found, European Wine Investment Found. Zob. B. Coffman, R. Nance, Wine: The Illiquid Liquid Investment Asset, "Journal of Financial Planning" 2009, Vol. 22, s. 61-70.

${ }_{11}$ P. Masset, J. Weisskopf, Raise your Glass: Wine Investment and the Financial Crisis, 2010.

12 C. Smith, Liquid Gold: Is Fine Wine the New Reserve Commodity?, "Credit Control" 2010, Vol. 31, No. 5-6, s. $42-50$.

${ }^{13}$ L.W. Sanning, S. Shaffer, J.M. Sharratt, Bordeaux Wine as a Financial Investment, "Journal of Wine Economics" 2012, Vol. 3, No. 1, s. 51-71. 
Na podstawie danych z tabeli 1 można stwierdzić, że ostatnie opracowania dotyczące zyskowności omawianej inwestycji wskazują na jej wysoką stopę zwrotu. Jedynie najstarsze prace zawarte $\mathrm{w}$ tabeli 1 wskazują, że inwestycja $\mathrm{w}$ wino cechuje się niewiele wyższą stopą zwrotu od bezpiecznej inwestycji w bony skarbowe. Opracowania 1 i 2 z analizowanej tabeli dotyczą jednak odległego okresu badawczego, tymczasem pozostałe publikacje opierają się na stopach zwrotu, które można było uzyskać $\mathrm{z}$ inwestycji w wino w ostatnich latach. Poziom stopy zwrotu $\mathrm{z}$ inwestycji w wino wskazuje zatem, że taka forma pomnażania kapitału może stanowić interesujący rodzaj aktywów, włączanych do portfela inwestycyjnego w celu zwiększania zysków.

Tabela 1. Stopa zwrotu z inwestycji na rynku sztuki - wyniki badania literaturowego

\begin{tabular}{|c|l|c|l|l|}
\hline Lp. & \multicolumn{1}{|c|}{ Poziom stopy zwrotu } & Okres badawczy & \multicolumn{1}{|c|}{ Badane wina } & Opracowanie \\
\hline 1 & $\begin{array}{l}\text { 0,64\% ponad oprocentowanie } \\
\text { bonów skarbowych }\end{array}$ & $1973-1977$ & $\begin{array}{l}\text { Czerwone wino z rejonu Bordeaux, } \\
\text { kalifornijskie wino Cabernet } \\
\text { Sauvignon, roczniki po 1950 }\end{array}$ & Krasker, 1979 \\
\hline 2 & $\begin{array}{l}12,39 \% \text { ponad oprocentowanie } \\
\text { bonów skarbowych }\end{array}$ & $1969-1977$ & $\begin{array}{l}\text { Czerwone wino z rejonu Bordeaux, } \\
\text { kalifornijskie wino Cabernet } \\
\text { Sauvignon, roczniki po 1950 }\end{array}$ & Jaeger, 1981 \\
\hline 3 & $\begin{array}{l}\text { 7,9\% średnia, roczna, nominalna } \\
\text { stopa zwrotu (3,1\% średnia, } \\
\text { roczna, realna stopa zwrotu) }\end{array}$ & $1986-1996$ & $\begin{array}{l}\text { czerwone wino z rejonu Bordeaux, } \\
\text { roczniki po 1960 }\end{array}$ & $\begin{array}{l}\text { Burton, } \\
\text { Jacobsen, 2001 }\end{array}$ \\
\hline 4 & $\begin{array}{l}146,86 \% \text { stopa zwrotu dla } \\
\text { przyjętego okresu badawczego }\end{array}$ & $\begin{array}{l}1996-2009 \\
\text { wina z Francji (rejon Bordeaux, } \\
\text { Burgundy i Rhône Valley), } \\
\text { oraz wina Włoskie i ze Stanów } \\
\text { Zjednoczonych }\end{array}$ & $\begin{array}{l}\text { Masset, } \\
\text { Weisskopf, 2010 }\end{array}$ \\
\hline 5 & $\begin{array}{l}\text { 0,51\% średnia, miesięczna stopa } \\
\text { zwrotu }\end{array}$ & $1996-2003$ & $\begin{array}{l}\text { czerwone wino z rejonu Bordeaux, } \\
\text { roczniki 1893-1998 }\end{array}$ & $\begin{array}{l}\text { Sanning i in., } \\
2012\end{array}$ \\
\hline
\end{tabular}

Źródło: Opracowanie własne.

W literaturze można także odnaleźć opracowania, które są próbą określenia determinant powodzenia inwestycji w wino. Do cech, które mają wpływ na cenę trunku, należy zaliczyćc ${ }^{14}$ :

- reputację winnicy, która wytwarza dany gatunek wina,

- warunki klimatyczne,

- rocznik wina,

- warunki pogodowe dla danego rocznika (np. temperatura powietrza, liczba dni deszczowych) w trakcie dojrzewania i zbioru winorośli,

- region położenia winnicy,

14 O. Ashenfelter, Predicting the quality and prices of Bordeaux Wine, "The Economic Journal" 2008, Vol. 118, s. F174 - F185; B. Coffman, R. Nance, Wine: The Illiquid Liquid Investment Asset, "Journal of Financial Planning" 2009, Vol. 22, s. 61-70; H. Hadj Ali, L. Sebastien, M. Visser, The impact of Gurus: Parker grades and En Primeur wine prices, "The Economic Journal" 2008, Vol. 118, F158 - F174. 
- ocenę przyznawaną przez sommelierów,

- technologię wytwarzania oraz warunki przechowywania wina i stan butelek,

- ceny poprzednich roczników.

Celem poniższego opracowania jest pogłębienie wiedzy na temat powiązań między ceną wina a oceną przyznawaną przez sommelierów, ponadto analizie poddano związek pomiędzy ceną wybranych trunków a ich rocznikiem i liczbą sklepów, które prowadzą sprzedaż danego wina. Tak przeprowadzona analiza pozwoli na określenie siły i kierunku, z jakimi te kluczowe czynniki wpływają na stopę zwrotu z inwestycji w wino.

\section{Dane użyte do analizy}

W pracy posłużono się danymi zaczerpniętymi ze strony internetowej: http://90pluswines.com ${ }^{15}$. Do analizy wykorzystano ceny ośmiu szczepów winnych ${ }^{16}$ wytwarzanych we Francji, największego producenta win na świecie ${ }^{17}$. Wszystkie wina, których ceny analizowano, pochodzą z rejonu Bordeaux, z którego wywodzi się większość win inwestycyjnych ${ }^{18}$. Poza ceną dla poszczególnych roczników win, zgromadzono także dane odnośnie do oceny przyznawanej przez sommelierów i liczby sklepów oferujących dany gatunek i rocznik wina. Zestawienie podstawowych informacji na temat analizowanych gatunków win przedstawiono w tabeli 2.

W tabeli 2 przedstawiono nazwy win, których ceny zostały zbadane w dalszej części opracowania. Kolumna „liczba cen rzeczywistych” zawiera ceny, które faktycznie padły w transakcji. W następnej kolumnie podano liczbę cen prognozowanych. Te ceny znajdują się w ofercie dla poszczególnych win i roczników, jednak nie zostały potwierdzone przeprowadzeniem rzeczywistej transakcji. W ostatniej kolumnie podany jest rok najstarszego rocznika poddanego analizie. Przy badaniu korelacji i dla oszacowania modeli ekonometrycznych posłużono się cenami rzeczywistymi i prognozowanymi (cechy: rocznik i ocena sommeliera) lub wyłącznie rzeczywistymi (cecha: liczba sklepów).

\footnotetext{
15 To największa europejska baza związana z rynkiem win, której dane pochodzą od blisko 10 tys. handlarzy win, dane zostały pobrane 7.04.2014.

${ }^{16} \mathrm{Na}$ stronach http://90pluswines.com są dostępne dane jeszcze dwóch szczepów winnych Chateau d' Yquem/Sauternes i Chateau Lafite-Rothschild/Pauillac. Tych szczepów nie analizowano ze względu na znaczną liczbę cen prognozowanych oraz na fakt, że dla tych win dane dotyczą roczników z końca XVIII i początku XIX w., dostęp 7.04.2015.

${ }_{17}$ M. Mikita, W. Pełka, Rynki inwestycji alternatywnych, Poltext, Warszawa 2009, s. 226.

${ }_{18} \mathrm{Z}$ rejonu Bordeaux pochodzi blisko 90-95\% wszystkich win inwestycyjnych, pozostałe to wina burgundzkie i reńskie, Inwestycje alternatywne, red. I. Pruchnicka-Grabias, CeDeWu.pl, Warszawa 2008, s. 249.
} 
Tabela 2. Charakterystyka danych użytych w analizie

\begin{tabular}{|l|c|c|c|c|}
\hline \multicolumn{1}{|c|}{ Wino } & $\begin{array}{c}\text { Liczba } \\
\text { analizowanych } \\
\text { roczników }\end{array}$ & $\begin{array}{c}\text { Liczba cen } \\
\text { rzeczywistych }\end{array}$ & $\begin{array}{c}\text { Liczba cen } \\
\text { prognozowanych }\end{array}$ & $\begin{array}{c}\text { Najstarszy } \\
\text { analizowany } \\
\text { rocznik }\end{array}$ \\
\hline Chateau Ausone/Saint Emilion & 84 & 60 & 24 & 1874 \\
\hline Chateau Cheval Blanc/Saint Emilion & 84 & 64 & 20 & 1899 \\
\hline Chateau Haut Brion/Pessac Leognan & 67 & 66 & 1 & 1920 \\
\hline Chateau Latour/Pauillac & 94 & 77 & 17 & 1847 \\
\hline Chateau Le Pin/Pomerol & 32 & 30 & 2 & 1979 \\
\hline Chateau Margaux/Margaux & 92 & 71 & 21 & 1847 \\
\hline Chateau Mouton Rothschild/Pauillac & 97 & 85 & 12 & 1870 \\
\hline Petrus/Pomerol & 59 & 55 & 4 & 1900 \\
\hline Suma & 609 & 508 & 101 & $\mathrm{x}$ \\
\hline
\end{tabular}

Źródło: Opracowanie własne.

Wybrane statystyki opisowe oceny win, ich ceny oraz liczby sklepów prowadzących dystrybucję przedstawiono $\mathrm{w}$ tabeli 3 .

Tabela 3. Średnia, minimalna i maksymalna ocena, cena i liczba sklepów

\begin{tabular}{|l|c|c|c|c|c|c|c|c|}
\hline \multirow{2}{*}{ Wino } & \multicolumn{3}{|c|}{ Ocena } & \multicolumn{3}{c|}{ Cena (w USD) } & \multicolumn{2}{c|}{ Liczba sklepów } \\
\cline { 2 - 10 } & Średnia & Min. & Max & Średnia & Min. & Max & Średnia & Max \\
\hline Chateau Ausone/Saint Emilion & 86,68 & 72 & 99 & 1146,10 & 226 & 7334 & 9,48 & 31 \\
\hline Chateau Cheval Blanc/Saint Emilion & 86,63 & 57 & 98 & 881,32 & 194 & 7539 & 9,14 & 34 \\
\hline Chateau Haut Brion/Pessac Leognan & 90,01 & 73 & 99 & 956,91 & 206 & 9954 & 23,15 & 74 \\
\hline Chateau Latour/Pauillac & 88,26 & 50 & 99 & 2301,99 & 240 & 26858 & 19,10 & 78 \\
\hline Chateau Le Pin/Pomerol & 92,16 & 82 & 98 & 2217,28 & 963 & 10320 & 7,30 & 16 \\
\hline Chateau Margaux/Margaux & 88,78 & 55 & 98 & 1898,65 & 233 & 18944 & 19,07 & 69 \\
\hline Chateau Mouton Rothschild/Pauillac & 85,55 & 55 & 99 & 2413,54 & 192 & 48208 & 21,54 & 90 \\
\hline Petrus/Pomerol & 92,86 & 79 & 98 & 2988,44 & 993 & 17350 & 14,85 & 34 \\
\hline
\end{tabular}

Źródło: Opracowanie własne.

Tak jak przedstawiono w tabeli 3, najniższą średnią ocenę wśród 10 rozpatrywanych win otrzymał Mouton Rothschild/Pauillac, poniżej 86 punktów. O niskich ocenach tego właśnie gatunku zdecydowały niskie oceny dla roczników starszych niż 1925. Przy uwzględnieniu tylko win z roczników od 1925 włącznie średnia ocena dla tego szczepu przekracza 87 punktów. Liczba punktów określająca jakość wina jest wyliczona jako średnia z ocen przyznawanych przez profesjonalnych sommelierów ${ }^{19}$.

19 Posłużono się tutaj miarą jakości wina określoną jako UWS (Universal Wine Score). Przy wyliczaniu UWS posłużono się ocenami dokonanymi m.in. przez R. Parkera, WineSpectator, Burghound. 
Przy wyliczaniu UWS uwzględnia się zatem różną liczbę ocen w zależności od liczby sommelierów, którzy dokonali oceny danego rocznika i szczepu. Im wyższa liczba punktów, tym lepszej jakości wino. W kolejnych kolumnach tabeli 3 przedstawiono także średnią, minimalną i najwyższą cenę dla każdego analizowanego szczepu. Wszystkie ceny przedstawione w opracowaniu są podane w USD. Najniższą i najwyższą cenę w badanej próbie zanotowano dla tego samego wina Chateau Mouton Rothschild/Pauillac. Średnią najniższą ceną cechowało się wino Chateau Cheval Blanc/Saint Emilion, zaś najwyższą średnią cenę uzyskał szczep Petrus/Pomerol. Ponadto $\mathrm{w}$ analizie wykorzystano również dane na temat liczby sklepów oferujących dany szczep i rocznik wina. $\mathrm{W}$ analizie uwzględniono jedynie wina, które można było nabyć (były w ofercie przynajmniej jednego sklepu), dlatego minimalna liczba sklepów sprzedająca dany gatunek wina dla każdego rocznika wynosi 1 i nie została przedstawiona w tabeli. W wypadku maksymalnej liczby sklepów najwięcej, bo aż 90, oferowało wino Chateau Mouton Rothschild/Pauillac. Jednak średnio najwięcej sklepów oferowało wino Chateau Haut Brion/Pessac Leognan.

\section{Wybrane czynniki determinujące zwrot z inwestycji w wino - badanie korelacji}

Analizie poddano związek pomiędzy ceną wina oraz:

- oceną przyznawaną przez sommelierów,

- liczbą sklepów, które oferują dany szczep i rocznik,

- rocznikiem.

W ocenie siły i kierunku związku pomiędzy analizowanymi danymi posłużono się współczynnikiem korelacji liniowej Pearsona. Współczynnik wyliczono według formuły ${ }^{20}$ :

gdzie:

$$
r_{X Y}=\frac{\operatorname{cov}(X, Y)}{\sigma_{X} \sigma_{Y}}
$$

$\mathrm{r}_{\mathrm{XY}}$ - współczynnik korelacji liniowej Pearsona dla próby,

$\sigma_{\mathrm{X}}-$ odchylenie standardowe zmiennej $\mathrm{X}$,

$\sigma_{Y}$ - odchylenie standardowe zmiennej $Y$,

$\operatorname{cov}(\mathrm{X}, \mathrm{Y})$ - kowariancja zmiennej X i Y.

\footnotetext{
${ }^{20}$ A. Luszniewicz, T. Słaby, Statystyka $z$ pakietem komputerowym Statistica PL. Teoria i zastosowanie, C.H. Beck, Warszawa 2008, s. 286-296.
} 
$\mathrm{R}_{\mathrm{xy}}$ przyjmuje wartości z przedziału $<-1,1>$. Można stwierdzić, że jeżeli wartość współczynnika korelacji jest zbliżona do 0 , wówczas nie ma liniowego związku pomiędzy badanymi zmiennymi. Wartość współczynnika równa +1 oznacza bardzo silny dodatni związek pomiędzy badanymi zmiennymi. W ślad za wzrostem wartości jednej zmiennej będzie wzrastała wartość drugiej zmiennej. Dla wartości współczynnika równej -1, pomiędzy badanymi cechami można wskazać silny i ujemny związek. Będzie to oznaczało, że jeśli spadnie wartość jednej cechy, wartości drugiej cechy będą wzrastały. Przy badaniu korelacji szczególny nacisk kładzie się także na badanie istotności wyliczonego wskaźnika. Jeżeli przez $\rho$ oznaczymy wartość współczynnika korelacji w populacji, to układ testowanych hipotez przedstawia się następująco:

$$
\begin{aligned}
& \mathrm{H}_{0}: \rho=0 \\
& \mathrm{H}_{1}: \rho=0
\end{aligned}
$$

Istotność testu jest weryfikowana testem t-Studenta o n-2 stopniach swobody. Wartości współczynników korelacji liniowej Pearsona wyliczone dla badanych szczepów winnych przedstawiono w tabeli 4 .

Tabela 4. Wartość i istotność korelacji pomiędzy ceną wina a jego rocznikiem, liczbą

\begin{tabular}{|c|c|c|c|c|c|c|c|c|}
\hline & 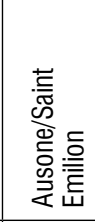 & 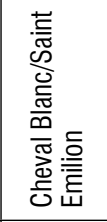 & 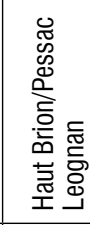 & 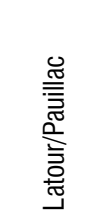 & 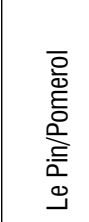 & 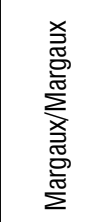 & 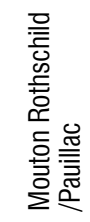 & 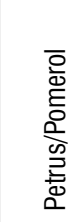 \\
\hline Rocznik & $-0,63^{*}$ & $-0,39 *$ & $-0,60$ * & $-0,65^{\star}$ & $-0,29$ & $-0,66^{*}$ & $-0,56^{*}$ & $-0,54^{*}$ \\
\hline Liczba sklepów & $-0,14$ & $-0,24^{* *}$ & $-0,40^{*}$ & $-0,23^{*}$ & $-0,18$ & $-0,26^{\star}$ & $-0,40^{*}$ & $-0,42^{*}$ \\
\hline Ocena UWS & $0,23^{*}$ & $0,18^{* *}$ & 0,09 & $0,17^{\star \star}$ & $0,38^{*}$ & $0,19 * *$ & 0,10 & $0,36^{*}$ \\
\hline Liczba obserwacji (rocznik, UWS) & 84 & 84 & 67 & 94 & 32 & 92 & 97 & 59 \\
\hline Liczba obserwacji (liczba sklepów) & 60 & 64 & 66 & 77 & 30 & 71 & 85 & 55 \\
\hline
\end{tabular}
sklepów i oceną

${ }^{*}$ Korelacja jest statystycznie istotna dla $\alpha=0,05$.

** Korelacja jest statystycznie istotna dla $\alpha=0,10$.

Źródło: Opracowanie własne.

Dla wszystkich analizowanych win można wskazać ujemną i silną korelację pomiędzy rocznikiem a ceną wina. Korelacja pomiędzy tymi charakterystykami jest dla wszystkich szczepów statystycznie istotna na poziomie $\alpha=0,05$, z wyjątkiem wina Le Pin/Pomerol, dla którego nie można mówić o statystycznej istotności na poziomie $\alpha \leq 0,10$. Jest to ten szczep, dla którego dysponowano najmniejszą liczbą 
obserwacji. Wartości ujemnej korelacji pomiędzy rocznikiem a ceną wina wskazują na silną zależność. Oznacza to, że im wcześniej wyprodukowano dane wino, tym jego cena jest wyższa.

Podobną zależność, chociaż o mniejszej sile, zaobserwowano dla ceny wina i liczby sklepów, które oferują dane gatunki do sprzedaży. Im wyższa cena, tym mniej sklepów oferuje dany trunek. Wartość siły korelacji tych cech można określić jako umiarkowaną. Droższe wina wymagają wyższych nakładów inwestycyjnych, powoduje to, że mniej sklepów jest zainteresowanych ich pozyskaniem. Specyfiką inwestycji w wino jest zatem ograniczona podaż starszych roczników. Konsumpcja wina powoduje bowiem, że w obrocie pozostaje coraz mniej win z tych roczników. Maleje zatem także możliwość pozyskania ich przez sklepy, nawet gdyby wysokie nakłady inwestycyjne nie były dla sprzedawców przeszkodą.

Ostatnie z badanych powiązań dotyczy ceny wina oraz oceny przyznawanej przez sommelierów. Jedynie dla trzech gatunków win można mówić o istotnej statystycznie oraz umiarkowanej korelacji dodatniej. Te trzy rodzaje wina to:

- Ausone/Saint Emilion,

- Le Pin/Pomerol,

- Petrus/Pomerol.

Dla wyżej wymienionych szczepów wraz ze wzrostem oceny dokonanej przez sommeliera obserwuje się jednoczesny wzrost ceny. Również dla trzech win odnotowano słaby związek korelacyjny na poziomie istotności $\alpha=0,10$. Dla dwóch szczepów odnotowano brak związku korelacyjnego pomiędzy oceną wina a ceną. Stoi to $\mathrm{w}$ sprzeczności z wcześniej zapisanymi wnioskami ${ }^{21}$. Przyczyną odmiennych wyników niż we wcześniej prowadzonych badaniach może być fakt, że w poniższym opracowaniu posłużono się średnią oceną wina, którą wyliczono na podstawie pojedynczych ocen wielu sommelierów. Ponadto badane próby zawierają także wina z roczników z XIX w., które charakteryzują się niższymi ocenami niż te z roczników najmłodszych. Wpływa to na ogólny wynik badania korelacji, co więcej fakt niskich ocen dla najstarszych roczników należy łączyć z rozwojem technologii wytwarzania wina, co sprzyja poprawie ocen dla win najmłodszych.

${ }^{21}$ B. Coffman, R. Nance, Wine: The Illiquid Liquid Investment Asset, "Journal of Financial Planning” 2009, Vol. 22, s. 61-70; H. Hadj Ali, L. Sebastien, M. Visser, The impact of Gurus: Parker grades and En Primeur wine prices, "The Economic Journal” 2008, Vol. 118, s. F158 - F174. 


\section{Model wyceny wina}

Dla każdego badanego szczepu winnego oszacowano model ekonometryczny, w którym zmienna objaśniana to cena wina. Lepsze właściwości uzyskiwano dla postaci wykładniczej modelu niż dla postaci liniowej. Model, który oszacowano dla każdego analizowanego wina, ma postać:

$$
\ln Y=a R+b U W S+c L S+\xi
$$

gdzie:

$\mathrm{Y}$ - cena wina,

$\mathrm{R}$ - rocznik wina,

UWS - ocena wina,

LS - liczba sklepów,

a,b,c - parametry modelu,

$\xi$ - składnik losowy.

W tabeli 5 zestawiono wyniki regresji dla analizowanych cen ośmiu szczepów winnych.

Tabela 5. Wyniki regresji

\begin{tabular}{|c|c|c|c|c|c|}
\hline Wino & $\begin{array}{c}\text { Zmienna } \\
\text { objaśniająca }\end{array}$ & Współczynnik & $\begin{array}{c}\text { Błąd } \\
\text { standardowy }\end{array}$ & t-Studenta & wartość p \\
\hline \multirow{2}{*}{$\begin{array}{l}\text { Chateau Ausone } \\
\text { Saint Emilion }\end{array}$} & Rocznik & $-0,019$ & 0,002 & $-12,39$ & 0,0000 \\
\hline & UWS & 0,054 & 0,008 & 6,99 & 0,0000 \\
\hline \multirow{2}{*}{$\begin{array}{l}\text { Chateau Cheval Blanc } \\
\text { Saint Emilion }\end{array}$} & Rocznik & $-0,022$ & 0,002 & $-10,30$ & 0,0000 \\
\hline & UWS & 0,048 & 0,007 & 6,74 & 0,0000 \\
\hline \multirow{2}{*}{$\begin{array}{l}\text { Chateau Haut Brion } \\
\text { Pessac Leognan }\end{array}$} & Rocznik & $-0,032$ & 0,003 & $-11,74$ & 0,0000 \\
\hline & UWS & 0,076 & 0,012 & 6,31 & 0,0000 \\
\hline \multirow{2}{*}{$\begin{array}{l}\text { Chateau Latour } \\
\text { Pauillac }\end{array}$} & Rocznik & $-0,025$ & 0,002 & $-15,75$ & 0,0000 \\
\hline & UWS & 0,033 & 0,007 & 4,81 & 0,0000 \\
\hline \multirow{2}{*}{$\begin{array}{l}\text { Chateau Le Pin } \\
\text { Pomerol }\end{array}$} & Rocznik & $-0,027$ & 0,007 & $-3,64$ & 0,0010 \\
\hline & UWS & 0,097 & 0,020 & 4,74 & 0,0001 \\
\hline \multirow{2}{*}{$\begin{array}{l}\text { Chateau Margaux } \\
\text { Margaux }\end{array}$} & Rocznik & $-0,024$ & 0,001 & $-19,88$ & 0,0000 \\
\hline & UWS & 0,048 & 0,006 & 7,73 & 0,0000 \\
\hline \multirow{2}{*}{$\begin{array}{l}\text { Chateau Mouton } \\
\text { Rothschild/Pauillac }\end{array}$} & Rocznik & $-0,034$ & 0,002 & $-16,44$ & 0,0000 \\
\hline & UWS & 0,028 & 0,007 & 3,92 & 0,0002 \\
\hline \multirow{2}{*}{$\begin{array}{l}\text { Petrus } \\
\text { Pomerol }\end{array}$} & Rocznik & $-0,016$ & 0,002 & $-6,94$ & 0,0000 \\
\hline & UWS & 0,082 & 0,014 & 5,72 & 0,0000 \\
\hline
\end{tabular}

Źródło: Opracowanie własne.

Wartości, które przedstawiono w tabeli 5 wyliczono za pomocą programu Gretl, przy wykorzystaniu metody najmniejszej kwadratów. Dla wszystkich analizowanych win statystycznie istotne, przy budowie modelu wyjaśniającego zmienność ceny, 
okazały się te same dwie cechy - rocznik oraz ocena. Te same zmienne okazują się statystycznie istotne przy wykorzystaniu metody regresji krokowej wstecznej przeprowadzonej za pomocą programu Statistica. W żadnym modelu statystycznie istotna nie okazała się zmienna liczba sklepów. Oznacza to, że w ramach skonstruowanych modeli cecha „liczba sklepów, które oferują wino do sprzedaży” nie wpływa na jego wycenę. Oszacowane modele wyceny wina można zatem zapisać tak, jak w tabeli 6 .

Tabela 6. Funkcje ceny dla analizowanych szczepów winnych

\begin{tabular}{|l|l|}
\hline \multicolumn{1}{|c|}{ Wino } & Model \\
\hline Chateau Ausone/Saint Emilion & $\widehat{\ln Y}=-0,019 R+0,054 U W S+38,51$ \\
\hline Chateau Cheval Blanc/Saint Emilion & $\widehat{\ln Y}=-0,022 R+0,048 U W S+46,03$ \\
\hline Chateau Haut Brion/Pessac Leognan & $\widehat{\ln Y}=-0,032 R+0,076 U W S+63,51$ \\
\hline Chateau Latour/Pauillac & $\widehat{\ln Y}=-0,025 R+0,033 U W S+53,50$ \\
\hline Chateau Le Pin/Pomerol & $\widehat{\ln Y}=-0,027 R+0,097 U W S+52,70$ \\
\hline Chateau Margaux/Margaux & $\widehat{\ln Y}=-0,024 R+0,048 U W S+48,89$ \\
\hline Chateau Mouton Rothschild/Pauillac & $\widehat{\ln Y}=-0,034 R+0,028 U W S+70,52$ \\
\hline Petrus/Pomerol & $\widehat{\ln Y}=-0,016 R+0,082 U W S+31,86$ \\
\hline
\end{tabular}

Źródło: Opracowanie własne.

Wyniki, które otrzymano dla wina Chateau Ausone/Saint Emilion można zinterpretować w następujący sposób:

- $\quad$ k każdym kolejnym rokiem pochodzenia wina jego cena zmniejszała się przeciętnie o $\left(e^{-0,019}-1\right)=-1,88 \%$, przy średnim błędzie wynoszącym $0,2 \%$ oraz przy stałości pozostałych czynników,

- wraz ze wzrostem oceny o jeden punkt jego cena wzrastała przeciętnie o $\left(e^{0,054}-1\right)=5,55 \%$, przy średnim błędzie wynoszącym $0,8 \%$ oraz przy stałości pozostałych czynników.

Analogiczne interpretacje można zapisać dla pozostałych analizowanych szczepów, wykorzystując dane przedstawione w tabeli 6. Najwyższą wartość dla zmiennej „rocznik”, odnotowano dla szczepu Chateau Mouton Rothschild/Pauillac, dla którego zmiana rocznika na to samo wino, ale o rok starsze, skutkowała przeciętnym wzrostem ceny o 3,34\%. Można zatem stwierdzić, że na tym winie powinno się zarabiać najszybciej. Najwolniejszy przyrost zainwestowanego kapitału zaobserwowano dla wina Petrus/Pomerol. Dla tego szczepu zmiana rocznika na to samo wino, ale o rok starsze, skutkowała przeciętnym wzrostem ceny o 1,59\%.

W wypadku punktowej oceny wina, najmniej wrażliwe na wartość oceny okazało się wino, które najszybciej zyskuje na wartości, czyli Chateau Mouton Rothschild/Pauillac. Dla tego wina wzrost oceny o jeden punkt skutkował przeciętnym 
wzrostem ceny o 2,84\%. Z kolei wino ze szczepu Chateau Le Pin/Pomerol odznacza się największą wrażliwością na oceny przyznawane przez sommelierów. Spadek oceny o jeden punkt skutkuje dla tego szczepu przeciętnym spadkiem ceny o 10,17\%. Na rysunku 1 zobrazowano dla każdego szczepu czas potrzebny na podwojenie się zainwestowanego kapitału. Kolejna seria danych przedstawia liczbę punktów oceny wina, której wzrost również powoduje podwojenie zainwestowanej kwoty.

\section{Rysunek 1. Liczba lat i liczba punktów UWS gwarantująca podwojenie się zainwestowanego kapitału}

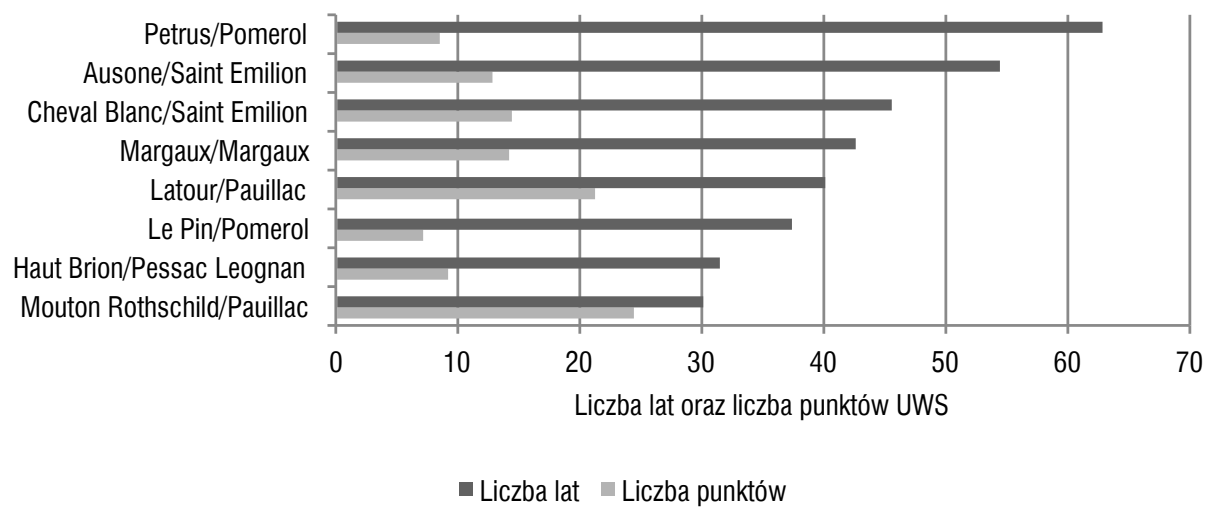

Źródło: Opracowanie własne.

Na podstawie danych zaprezentowanych na rysunku 1 można stwierdzić, że najkrócej, bo blisko po 30 latach zainwestowany kapitał podwaja się dla wina Chateau Mouton Rothschild/Pauillac. Dla win Chateau Ausone/Saint Emilion oraz Petrus/Pomerol uzyskanie stopy zwrotu $\mathrm{z}$ inwestycji na poziomie $100 \%$ zajmuje ponad 50 lat. Czynnikiem, który z większą siłą oddziałuje na cenę wina jest ocena, dokonywana przez sommelierów. Dla wina Le Pin/Pomerol zmiana o blisko 7 punktów skutkuje zmianą w stopie zwrotu $z$ inwestycji na poziomie 100\%. Najmniej wrażliwe na ocenę krytyków wina są trunki Latour/Pauillac oraz Mouton Rothschild/Pauillac. To, że wpływ oceny na cenę wina jest wyższy, widać również, jeżeli otrzymane wyniki dla ośmiu analizowanych szczepów winnych zostaną uśrednione.

Okazuje się, że średnio zmiana rocznika wina na rocznik o rok starszy powoduje wzrost ceny o $2,46 \%$. W wypadku wzrostu oceny wina o jeden punkt, zmiana w cenie wina wynosi średni $6,01 \%$. Efekt zmiany oceny wina o jeden punkt jest zatem blisko 2,5 razy silniejszy niż zmiana rocznika o rok. Nie można natomiast mówić o statystycznej istotności zmiennej objaśniającej „liczba sklepów”. Dla tej zmiennej dla żadnego wina nie zaobserwowano istotnego wpływu na cenę. 
W tabeli 7 zobrazowano z kolei wartość podstawowych miar dopasowania dla wyznaczonych modeli.

Tabela 7. Funkcje ceny dla analizowanych szczepów winnych

\begin{tabular}{|c|c|c|c|c|c|}
\hline Wino & $\begin{array}{c}\text { Współczynnik } \\
\text { determinacji R2 }\end{array}$ & $\begin{array}{c}\text { Skorygowany } \\
\text { współczynnik } \\
\text { determinacji } \text { R }^{2}\end{array}$ & $\begin{array}{c}\text { Błąd } \\
\text { standardowy } \\
\text { reszt } \mathrm{S}_{\mathrm{e}}\end{array}$ & $\begin{array}{c}\text { Średnia } \\
\text { arytmetyczna } \\
\text { zmiennej } \\
\text { zależnej }\end{array}$ & $\begin{array}{l}\text { Współczynnik } \\
\text { zmienności } \\
\text { resztowej } V_{e}\end{array}$ \\
\hline Ausone/Saint Emilion & 0,67 & 0,66 & 0,46 & 6,69 & 0,07 \\
\hline Cheval Blanc/Saint Emilion & 0,57 & 0,56 & 0,51 & 6,43 & 0,08 \\
\hline Haut Brion/Pessac Leognan & 0,69 & 0,68 & 0,52 & 6,34 & 0,08 \\
\hline Latour/Pauillac & 0,73 & 0,73 & 0,62 & 6,88 & 0,09 \\
\hline Le Pin/Pomerol & 0,47 & 0,44 & 0,37 & 7,56 & 0,05 \\
\hline Margaux/Margaux & 0,82 & 0,81 & 0,47 & 6,83 & 0,07 \\
\hline Mouton Rothschild/Pauillac & 0,75 & 0,74 & 0,63 & 6,89 & 0,09 \\
\hline Petrus/Pomerol & 0,57 & 0,55 & 0,44 & 7,74 & 0,06 \\
\hline
\end{tabular}

Źródło: Opracowanie własne.

Zakładając graniczną wartość współczynnika zmienności resztowej na poziomie 0,10, można stwierdzić, że wszystkie oszacowane modele nadają się do praktycznego wykorzystania ${ }^{22}$. Najwyższą ocenę stopnia wyjaśnienia zmienności ceny wina odnotowano dla wina Margaux. Dla tego modelu skorygowany współczynnik determinacji $\mathrm{R}^{2}$ wynosi ponad 0,81 , co oznacza, że $81 \%$ zmienności zmiennej zależnej zostało wyjaśnione przez skonstruowany model. Ponad 65\% zmienności zmiennej zależnej wyjaśniono dla czterech win:

- Ausone/Saint Emilion,

- Haut Brion/Pessac Leognan,

- Latour/Pauillac,

- Mouton Rothschild/Pauillac.

Dla pozostałych trunków współczynniki determinacji są na niższym poziomie, co oznacza, że zmienność ich ceny jest w mniejszym stopniu wyjaśniona przez oszacowane modele.

22 T. Kufel, Ekonometria. Rozwiązywanie problemów z wykorzystaniem programu GRETL, PWN, Warszawa 2013, s. 58-59. 


\section{Podsumowanie}

Wyniki zaprezentowanych badań potwierdzają, że kluczowe zmienne przy wycenie wina to rocznik i ocena sommelierów. Statystycznie nieistotną zmienną, przy budowie modelu ekonometrycznego wyjaśniającego zmienność ceny, jest liczba sklepów prowadząca sprzedaż danych szczepów. Wyniki badania korelacji potwierdzają jednak, że im mniejsza liczba sklepów, która sprzedaje dany gatunek wina, tym jego cena jest wyższa. Najsilniejszy związek jest jednak obserwowany pomiędzy ceną wina $\mathrm{i}$ jego rocznikiem. Zbudowane modele $\mathrm{w}$ zadowalającym stopniu wyjaśniają zmienność ceny. Przedstawione wyniki wskazują także na fakt, że wino to inwestycja długoterminowa. Wykazano bowiem, że średnio zmiana rocznika wina na rok starszy powoduje wzrost ceny o $2,46 \%$. Natomiast w wypadku wzrostu oceny wina o jeden punkt, zmiana w cenie wina wynosi średnio $6,01 \%$.

\section{Bibliografia}

Ashenfelter O., Predicting the quality and prices of Bordeaux Wine, "The Economic Journal" 2008, Vol. 118.

Burton B.J., Jacobsen J.P., The Rate of Return on Investment in Wine, "Economic Inquiry" 2001, Vol. 39(3).

Campbell R., Fine violins as an alternative investment: Strings attached?, "Pensions: An International Journal" 2008, Vol. 13, No. 1-2.

Chmielarz W., Wino, czyli alternatywa, „Puls Biznesu” 3.07.2008.

Coffman B., Nance R., Wine: The Illiquid Liquid Investment Asset, "Journal of Financial Planning" 2009, Vol. 22.

Drewnowska B., Inwestycje w wino moga być alternatywa dla akcji, „Rzeczpospolita” 17.04.2008.

Gómez-Bezares F., Larreina M., An Approach to the Valuation of Rioja Wine, "Journal of Wine Research" 2008, Vol. 19, No. 1.

Hadj Ali H., Sebastien L., Visser M., The impact of Gurus: Parker grades and En Primeur wine prices, "The Economic Journal" 2008, Vol. 118.

Jaeger E., To Save of Savor The Rate of Return to Storing Wine, "Journal of Political Economy" 1981, Vol. 89.

Jovanovic B., Bubbles in prices of exhaustible resources, "International Economic Review" 2013, Vol. 54, No. 1. 
Krasker W.S., The Rate of Return to Storing Wines, "Journal of Political Economy" 1979, Vol. 87.

Kufel T., Ekonometria. Rozwiązywanie problemów z wykorzystaniem programu GRETL, PWN, Warszawa 2013.

Luszniewicz A., Słaby T., Statystyka z pakietem komputerowym Statistica PL. Teoria i zastosowanie, C.H. Beck, Warszawa 2008.

Masset P., Weisskopf J., Raise your Glass: Wine Investment and the Financial Crisis, 2010.

Mikita M., Pełka W., Rynki inwestycji alternatywnych, Poltext, Warszawa 2009.

Morningstar and Barron's, 2012 Alternative Investment Survey of U.S. Institutions and Financial Advisors, 2013.

Pruchnicka-Grabias I., Inwestycje alternatywne, CeDeWu.pl, Warszawa 2008.

Sanning L.W., Shaffer S., Sharratt J.M., Bordeaux Wine as a Financial Investment, "Journal of Wine Economics", Vol. 3, No. 1, 2012.

Smith C., Liquid Gold: Is Fine Wine the New Reserve Commodity?, "Credit Control” 2010, Vol. 31, No. 5-6.

Veld C., Veld-Merkoulova Y.V., Benefits of Investing in Stamps, "The Journal of Alternative Investments" 2007.

\section{Investment in Wine: Evaluation of Sommeliers, Year of Wine and Number of Distribution Points and Pricing}

The paper uses Pearson correlation coefficients to analyze strength and direction of the interaction between: price of the wine and the vintage, the evaluation made by sommeliers and wine price, price of wine and number of distribution points. Eight wine strains from the region of Bordeaux were analyzed. The strongest association was observed between the price of wine and vintage. The article also presents selected descriptive statistics for the price of wine, the assessment provided by sommeliers and the number of distribution points. On average, wine called Petrus / Pomerol enjoys the highest recognition of sommeliers. Furthermore, estimated econometric models indicate that the average price of the analyzed strains increased by $2.46 \%$ a year while the change in the evaluation of wine by one point affects the average change in price by $6.01 \%$.

Keywords: alternative investments, investment in wine, determinants of investment 


\section{Investir dans le vin: évaluation des sommeliers, millésime, nombre de points de distribution, prix}

Lauteur utilise des coefficients de corrélation de Pearson pour analyser la force et la direction de l'interaction entre: le prix du vin et le millésime, l'évaluation par des sommeliers et le prix du vin, le prix du vin et le nombre de points de distribution. Huit souches de vin de la région de Bordeaux ont été analysées. La relation la plus forte a été observée entre le prix du vin et le millésime. L'article présente également des statistiques descriptives sélectionnées pour le prix du vin, l'évaluation des sommeliers et le nombre de points de distribution. En moyenne, le vin appelé Petrus / Pomerol est caractérisé par la plus haute reconnaissance parmi les sommeliers. En outre, les modèles économétriques estimés indiquent que le prix moyen des souches de vin analysées a augmenté de $2.46 \%$ par an, tandis que le changement dans l'évaluation de vin d'un point affecte la variation moyenne du prix par $6.01 \%$.

Mots clés: les investissements alternatifs, l'investissement dans le vin, les déterminants de l'investissement

\section{Инвестиции в вино - оценка сомелье, год изготовления вина, количество распределительных пунктов и ценообразование}

В разроботке, при использовании коэффициента корреляции Пирсона, определяется силу и направление взаимодействия между: ценой на вино и годом изготовления, ценой вина и оценкой сомелье, и ценой вина и количеством точек распространения. Были проанализированы восемь сортов винограда из региона Бордо. Сильная связь наблюдалась между ценой вина и годом изготовления вина. В исследовании были также учтены избранные описательные статистики цен вина, оценок предоставленных сомелье и количества точек распространения. В среднем, высшим признанием сомелье пользовалось вино под названием Petrus/Pomerol. Кроме того, на основании использованных эконометрических моделей, можно заметить, что с конца каждого года средняя цена анализируемых сортов увеличивается на 2,46\%. Изменение в оценке вина на один пункт приводит к среднему изменению в цене на 6,01\%.

Ключевые слова: альтернативные инвестиции, инвестиции в вино, детерминанты инвестиций 
